\title{
Effect of Parental Modelling, Parental Control, and Information Exposure on Food Selection
}

\author{
Hilda Fauziah* \\ Department of Family and Consumer \\ Sciences, Faculty of Human Ecology, \\ Bogor Agricultural University
}

\author{
Lilik Noor Yuliati \\ Department of Family and Consumer \\ Sciences, Faculty of Human Ecology, \\ Bogor Agricultural University
}

\begin{abstract}
Food selection is the way a person considers choosing foods to eat for some reasons - mood, simplicity, sensory appeal, a natural ingredient in food, price, weight control, familiarity, and ethical issues. This study aimed to analyze the influence of parental modeling, parental controls, and information exposure on food selection on college student. The scope in food selection in this study is limited to vegetables. The method in this study used a survey on adolescent perceptions towards the parents socialization in the past. Data were collected by self-administered, in which questionnaires were filled by the respondents of 288 IPB PPKU students selected with cluster random sampling. Data were analyzed using descriptive analysis, different test and multiple linear regression. Regression analysis showed that 30.5 percent of parental modeling variable in indirect modeling dimension and parental controls affected the food selection. Other variables, such as gender and age of the student's mother also influenced the food selection.
\end{abstract}

Keywords: parental controls, information exposure, parental modeling, food selection

\begin{abstract}
Abstrak. Pemilihan makanan adalah cara seseorang dalam mempertimbangkan memilih makanan untuk dikonsumsi dengan alasan kesehatan, suasana hati, kemudahan, daya tarik sensorik, kandungan alami dalam pangan, harga, pengendalian berat badan, familiaritas, dan masalah etika. Penelitian ini bertujuan untuk menganalisis pengaruh parental modelling, kontrol orang tua, dan paparan informasi terhadap pemilihan makanan pada mahasiswa. Ruang lingkup dalam pemilihan makanan dalam penelitian ini dibatasi pada sayur. Metode dalam penelitian ini menggunakan metode survei mengenai persepsi remaja terhadap sosialisasi orang tua di masa lalu. Data dikumpulkan secara self administered yaitu kuesioner di isi sendiri oleh responden yang melibatkan 288 mahasiswa PPKU IPB yang dipilih secara cluster random sampling. Data dianalisis menggunakan analisis deskriptif, uji beda, dan uji regresi linier berganda. Hasil uji regresi ini menjelaskan sebesar 30.5 persen variabel parental modelling pada dimensi indirect modelling dan kontrol orang tua mempengaruhi pemilihan makanan. Variabel lain, seperti jenis kelamin mahasiswa dan usia ibu juga berpengaruh terhadap pemilihan makanan.
\end{abstract}

Kata kunci : kontrol orang tua, paparan informasi, parental modelling, pemilihan makanan 


\section{Introduction}

Becoming adolescent means entering a critical period in which there is a transition from children into adults characterized by hormonal, physical, cognitive development changes, and starting to interact more with their environment; thus, behavior changes. One of the examples is eating behavior which they tend to eat either healthy or unhealthy food, including food choices, such as the consumption of vegetables and fruits (Thiruselvakumar et al. 2014).

Some studies show that the rate of vegetable consumption in adolescents is still relatively poor. According Evelhin et al. (2014), the majority of the Indonesian population, especially adolescents and adults rarely eat vegetables, but vegetables are foods that are rich in vitamins, minerals, and fiber. Based on the survey results, Basic Healthy Research in 2013 national consumption behavior of vegetable have no significant change to the data in 2007 that as many as 93.8 percent of adolescents aged 15-24 years consumed less vegetables according to the province in Indonesa. According to Perera and Madhujith (2012), students are a group of individuals in juvenile stages and the first stage of a person to make their own food choices. Sztainer et al. (1999) identifies the factors that influence the food selection on teenagers is the availability of food, the influence of parents in feeding behavior, situations, moods, prices, and media.

The food selection may also be influenced by socialization. Agent of socialization among parents, media, and friends. This is in line with Benton (2004) who said that parents have an important role in the food socialization. Palfreyman et al. (2014) also suggests that parents play an important role as a model for the child's eating behavior. Shek (2008) said that parents also usually control the child's behavior in the process of socialization.

College students are social groups that are in the stage of juvenile. They are exposed to unhealthy eating habits highly enough (Huang et al. 2003). Characteristics of students who come from different parts makes it possible to have different behavior and eating habits. Additionally, exposure to information through the media and friends is also a process of socialization that allows consumers to influence adolescents in the food selection. According Moschils and Chruchill (1978); Faber and Huh (2010) who states that teens who spend watching television could affect social motivation towards consumption that illustrate knowledge about the brand, product and social symbol. In addition, friends will also affect adolescents preferences related to a product and brand knowledge either directly or indirectly (Gunter and Frunham 1998; Hota and McGuiggan 2006).

The purpose of this study included: 1) identify the habits of vegetable eating to students before and after signing the IPB; 2) identify the student's characteristics, family characteristics, parental modeling, parental controls, exposure information, and the food selection based on gender; 3) analyze the relationship between student characteristics, family characteristics, parental modeling, parental controls, and exposure to eat, information with the food selection; 4) analyze the influence of student characteristics, family characteristics, parental modeling, parental controls, and exposure information on the food selection. 


\section{Method}

The food selection is influenced by social factors such as religion, class, education, and advertising (Yudkin 1956; Ogden, 2010). Children are one of the consumers who have earned the learning so that they can take decisions. One way to make children as consumers is through socialization that has happened since childhood to adulthood. Quite contributions of family as major social environment can be a place for a child to learn and develop positive experience regarding healthy foods (Goddess of 2013). Socialization done by parents from childhood will have an impact on the behavior of children in the future through a process of socialization to acquire the knowledge, skills and attitudes as a consumer to choose the goods or services according to their needs. Palfreyman et al. (2012) explained that food selection is related to food that is modeled by parents in children. Based on the research results by Bargiota et al. (2013), the control of parents, mother's education and peer influence in food selection of Greek adolescents. Knowledge is a cognitive foundation for the formation of attitudes, including the attitudes and behavior of people in the food selection (Rickert 1996; Bahria and Triyanti 2010). In addition, media plays a role as an agent of socialization and Abideen and Salaria (2009) suggested that children's eating preferences can rely on television advertising that can convey messages and information. Sabri et al. (2005) stated that friends can influence in selecting and buying as a source of information and reference.

This study used design cross sectional - research done within a certain time. The research was carried out exactly in the Bogor Institute of Agriculture (IPB). Election of research location is done by purposive technique. The data collection was done with the survey method using a self-administered questionnaire.

The population in this study was Strata-1 (S1) students of Bogor Agricultural University who were still active in the IPB and are in semester two (2) academic year 2015/2016. Total population in this study was students of General Competence Education Program (GCEP) of Bogor Agricultural University, that is, 3573 students. Sampling technique that used in this study was probability sampling technique, namely, the cluster random sampling based on the number of classes in GCEP i.e. 33 classes. These classes were divided into several groups consisting of classes $\mathrm{P}, \mathrm{Q}, \mathrm{R}, \mathrm{S}, \mathrm{T}$, and U. After that, they were randomly selected into clusters and finally there were three classes obtained, that is, P09, Q03 and R02 classes consisting of 326 college students in total. The next stage, after the three classes were obtained, there were as many as 288 students who meet the criteria that was taken care of by the parents until the age of 16 years.

This study used a quantitative approach and the type of data used in this study was primary and secondary data. Primary data were obtained from the questionnaire (self-administered questionnaire) which covered individual characteristics (age, sex, education, and pocket money per month), family characteristics (age of the parents, parental education, occupation of parents, and the parents' income), parental modeling (verbal modeling, behavioral modeling, indirect modeling), parental controls, information exposure (media and friends), and the food selection. Instruments of parental modeling were modified from 
Palfreyman et al. (2012) divided into three dimensions, namely verbal modeling, behavioral modeling, and indirect modeling and measured using the 15 statements that have been previously tested their reliability. Cronbach's alpha value in the variable parental modeling is equal to $0 \mathrm{P} 745$. Instruments of parental control were modified from Scheinfeld (2012). The questionnaire of parental controls was modified to be applied on the condition when a teenager still lived with his parents. Parental controls were measured using a 18 point statement by Cronbach's alpha 0.606. In the variable, information exprosure by media and a friend was measured using a 10 point statement. Instruments were modified from Yuliati et al. (2012) with a value of Cronbach's alpha of 0831. Variable food selection was measured using 35 statements. The instrument used was a modified Questionnaire Food Awards of Steptoe et al. (1995), which consisted of nine dimensions of health, mood, simplicity, sensory, natural ingredients in food, price, weight control, familiarity, and ethical issues. Cronbach's alpha value of food selection by 0.948 . GCEP vegetable eating habits of students before and after signing the IPB was measured using a questionnaire FFQ (Food Frequency Questionnaire) modified from Eertmans (2006) and it contained 3-point declaration. Measurement variables were measured using a Likert scale of 1 to 5 explaining that $1=$ strongly disagree, $2=$ disagree, $3=$ neutral, $4=$ agree, and $5=$ strongly agree.

The data obtained were then processed through a process of editing, coding, data entry, and data analysis using Microsoft Excel for Windows and the Statistical Package for Social Science (SPSS). Analysis of the data used was descriptive analysis and inference. Analysis deskripftid used to describe the distribution of respondents by student characteristics (gender and pocket money), family characteristics (age of the parents, parental education, occupation of parents, and the parents' income), as well as related research variables regarding parental modeling, controls parents, exposure information, and the selection of food. Inferential analysis used was different test independent sample t-test to analyze the differences in student characteristics and family characteristics, parental modeling, parental controls, exposure information, and the selection of food based on gender. Correlation test was used to analyze the relationship between variables, and regression test was used to analyze the influence of the factors that influence food selection.

\section{Characteristic of Students}

\section{Result}

The number of respondents in this study was 288 students in which the proportion of respondents was that there were more women by 58 percent than males by 42 percent. This was based on the total number of Bogor Agricultural University students based on the data from the Directorate of Administration and Education in 2015 which amounted to 16.080 students, with the proportion of female students (9.449) and male students (6.631). In addition, the students' pocket money came from parents and scholarships. The results of this study indicated that the largest proportion of the allowance on student male and female was in the range of Rp 600.001-1.000.000 respectively by 51.2 percent and 47.9 percent. Student allowance obtained in this study referred to the scholarships 
received by IPB students - Rp 600.000 per month in average. Different test results showed that there were significant differences $(\mathrm{p}<0.05)$ in pocket money between men and women.

\section{Characteristics of Student Families}

The results of this study indicated that the largest proportion of the number of family members of male and female student were in the family category with five to seven people respectively by 54.5 percent and 50.3 percent. Based on the age of the parents, it showed that the largest proportion of the age of the father $(56 \%)$ of male students was in the older age category, while the father's age female students $(53.5 \%)$ were in the category of middle age. In addition, maternal age students $(78.4 \%)$ of men and women were in the category of middle age with an average age of 46.3 years. The education level of the parents of students as much as 33.7 percent was high school. There were significant differences $(p<0.05)$ of father's education level between male students and female. Moreover, the largest proportion of the income of the parents of male and female student was in the range of $\mathrm{Rp} 1.000 .000$ to $\mathrm{Rp} 5.000 .000$ per month, respectively 52 percent and 62.2 percent.

\section{Vegetable Eating Habits}

The results of this study indicated that there were changes in food consumption of vegetables to students before and after signing the college. Before entering college, male students tended to eat vegetables with a half-cup serving, while the female students were apt to eat vegetables with a portion of one cup per day. However, after entering the college, both of male and female student just ate vegetables with a half-cup servings per day. The frequency of eating vegetables of male $(52.1 \%)$ and female $(60.5 \%)$ students changed. Before entering the college, they were accustomed to eating vegetables more than twice per day. However, after signing the college, male (38\%) and female (40.7\%) students ate vegetables only once a day. On the type of vegetables consumed by male and female students did not change before and after entered IPB whereas students tended to be accustomed to eating vegetables sauteed.

\section{Parental Modelling}

Parental modeling in this study is parental modeling by Palfreyman et al. (2012), which consists of three dimensions, namely through words (verbal modeling), through behavioral (behavioral modeling), and inadvertently (indirect modeling). The results in this study showed that there were three dimensions of parental modeling which were significantly different $(\mathrm{p}<0.05)$ between male and female (Table 1).

In verbal modeling, what parents did both on male and female students tended to say through the words of the unhealthy foods, particularly in girls. This was because female tended to control weight. Usually, the behavior of parents can make children try to do the same thing as the old man did. When dining with a parent, the child will tend to try new foods. The results in this study showed that girls imitated the behavior of their parents, and it was suspected that a mother was 
as a major role in influencing children. Moreover, gender equality allowed it to be an imitated behavior (behavioral modeling) by children.

Table 1 Achieved index mean of parental modeling by gender

\begin{tabular}{lcccc}
\hline Parental modelling & \multicolumn{4}{c}{ Index Mean } \\
\cline { 2 - 5 } & $\begin{array}{c}\text { Male } \\
(\mathrm{n}=121)\end{array}$ & $\begin{array}{c}\text { Female } \\
(\mathrm{n}=167)\end{array}$ & $\begin{array}{c}\text { Total } \\
(\mathrm{n}-288)\end{array}$ & p-value \\
\hline Verbal modelling & $59.2 \pm 12.9$ & $64.2 \pm 12.2$ & $62.1 \pm 12.8$ & 0.001 \\
Behavioral modelling & $59.6 \pm 13.2$ & $63.0 \pm 12.9$ & $61.6 \pm 13.1$ & 0.030 \\
Indirect modelling & $60.3 \pm 15.7$ & $65.1 \pm 15.4$ & $63.1 \pm 15.6$ & 0.009 \\
\hline Total & $59.6 \pm 10.6$ & $63.9 \pm 10.1$ & $62.1 \pm 10.5$ & 0.001 \\
\hline
\end{tabular}

In addition, parental modeling which was inadvertently (indirect modeling) done by parents also can indirectly be adopted by the child. When boys and girls saw their parents did not eat vegetables, children would then indirectly choose not to eat vegetables. From the total average score performance index per dimension, parental modeling of the parents on the female students (63.9) was larger than that on the male students (57.3). Overall, parental modeling of the parents had significant different $(\mathrm{p}=0.001)$ for both male and female student.

\section{Parental Control}

Parental controls in this study was adopted and modified from Scheinfeld (2012). Parental controls are carried out may be the decision-making and restrictions. The results of this study showed that parents applied controls more in girls (51.9) than boys (49.5). Parental controls were carried out both in boys and girls who were more likely in the not given enough freedom in choosing foods that the child wants. That is, the chance to choose unhealthy foods can be suppressed by their parental controls to make choose healthy food like eating vegetables. This is because the use of parental controls was the response to unhealthy eating habits (Scaglioni et al., 2008). The results of different test independent sample t-test showed that there were significant differences $(p<0.05)$ in parental controls between boys and girls.

\section{Information Exposure}

Information exposure in this study was through the media and friends. The media was in the form of mass media, both print and electronic. Ten statements were given to the respondents to determine how big was the influence of the media and friends felt in the selection of healthy foods. Table 2 shows that male and female students are likely exposed to information through the media than by a friend. Different test results indicated that there was no significantly different information either through media exposure between male and female students $(p=0619)$. It was alleged that message conveyed through the media was like to get information about the benefits of vegetables from the media. Therefore, the knowledge increased with the frequency of spending time watching TV, which affected the social motivation towards consumption. According Bahria and Triyanti (2010), media is as a source of information assumed by watching television, teenagers do not need to spend money on information, and audiovisual forms of media could quickly receive information better and longer remember. 
In addition, this study also showed that there was no significant difference between the exposure of information through a friend of male and female students $(p=0.890)$, that is, male and female tended to have similarities to the information exposure through a friend. Influence of peers in adolescence was very strong, so it can influence the selection of food in order to gain acceptance from peers (Bahria and Triyanti 2010).

Table 2 Mean performance index of exposure information by gender

\begin{tabular}{lcccr}
\hline \multirow{1}{*}{ Information Exposure } & \multicolumn{3}{c}{ Index Mean } & p-value \\
\cline { 2 - 4 } & $\begin{array}{c}\text { Male } \\
(\mathrm{n}=121)\end{array}$ & $\begin{array}{c}\text { Female } \\
(\mathrm{n}=167)\end{array}$ & $\begin{array}{c}\text { Total } \\
(\mathrm{n}=288)\end{array}$ & \\
\hline Media & $60.0 \pm 15.3$ & $61.0 \pm 16.8$ & $60.6 \pm 16.2$ & 0.619 \\
Friends & $41.1 \pm 16.6$ & $40.8 \pm 20.1$ & $41.0 \pm 18.7$ & 0.890 \\
\hline
\end{tabular}

\section{Food Selection}

Based on the mean index (Table 3), there are three main reasons in the selection of foods, especially vegetables, namely health, mood, and weight control. First, the results showed that male and female student were concerned with health reasons in eating vegetables. This is because vegetables contain many vitamins, minerals, high in fiber, and can maintain a healthy body. In addition, male and female student have awareness on low health status so as to strive for a healthy lifestyle by choosing to eat vegetables. The mood is also pushing someone in choosing food. Second, the reason the mood in eating the food because students were aware of healthy lifestyles, and eating vegetables can make people feel better. This makes women have selfish reasons mood when eating vegetables. Thirdly, the reason for weight control with consideration for choosing vegetables was low in calories and low in fat. In these reasons, female students tended to be more concerned with weight control reasons than male. It is also associated with healthy behaviors in eating vegetables. Different test results showed that male students were more concerned with the price of reason eat vegetables because the price was cheap and affordable compared to that of female students $(p<0.05)$. Overall, there were no significant differences $(p=0.668)$ on food selection between male and female students. If seen by a total score of the average index score, achievements selection of food between male and female scores were relatively similar.

Table 3 Mean of performance index for the food selection (vegetables) by gender

\begin{tabular}{lcccc}
\hline Reason for food selection & \multicolumn{3}{c}{ Index Mean } & p-value \\
\cline { 2 - 4 } & $\begin{array}{c}\text { Male } \\
(\mathrm{n}=121)\end{array}$ & $\begin{array}{c}\text { Female } \\
(\mathrm{n}=167)\end{array}$ & $\begin{array}{c}\text { Total } \\
(\mathrm{n}=288)\end{array}$ \\
\hline Health & $74.5 \pm 17.4$ & $75.4 \pm 17.8$ & $75.0 \pm 17.6$ & 0.651 \\
Mood & $66.6 \pm 18.0$ & $66.3 \pm 17.8$ & $66.4 \pm 17.9$ & 0.871 \\
Easy & $56.5 \pm 14.0$ & $55.1 \pm 15.3$ & $55.7 \pm 14.7$ & 0.412 \\
Sensory & $59.7 \pm 18.3$ & $58.3 \pm 19.6$ & $58.9 \pm 19.0$ & 0.546 \\
Natural ingredient in food & $57.6 \pm 22.4$ & $56.0 \pm 23.5$ & $56.7 \pm 23.0$ & 0.573 \\
Price & $62.0 \pm 20.1$ & $56.7 \pm 20.7$ & $58.9 \pm 20.6$ & $0.029 *$ \\
Weight control & $64.5 \pm 18.5$ & $67.1 \pm 19.1$ & $66.0 \pm 18.8$ & 0.252 \\
Familiarity & $64.2 \pm 19.6$ & $64.5 \pm 20.4$ & $64.4 \pm 20.1$ & 0.896 \\
Ethical issues & $61.6 \pm 17.3$ & $59.0 \pm 16.9$ & $60.1 \pm 17.1$ & 0.203 \\
\hline Total & $63.9 \pm 12.2$ & $63.2 \pm 13.7$ & $63.5 \pm 13.1$ & 0.668 \\
\hline
\end{tabular}




\section{Relationship of Parental Modelling, Parental Control, Exposure information with Elections Food}

Correlation test results showed that parental modeling and parental control had a relationship with the food selection, especially in the vegetable. Correlation test results showed the verbal dimension modeling which had a significantly positive relationship to health reasons $(\mathrm{r}=0223, \mathrm{p}<0: 01)$, $\operatorname{mood}(\mathrm{r}=0.170, \mathrm{p}$ $<0.01)$, a natural ingredient in food $(\mathrm{r}=0.170, \mathrm{p}<0.01)$, the control of body weight $(\mathrm{r}=0.145, \mathrm{p}<0.05)$, and ethical issues $(\mathrm{r}=0.175, \mathrm{p}<0: 01)$, that is, the higher the verbal modeling is done, the higher these reasons in the food selection, especially in vegetables. It showed that parents explained directly to the students about choosing to eat vegetables by considering the content of vitamins, minerals, fiber, foods that can help live healthier. Aroma and delicious flavor can control your weight, which do not contain harmful chemicals, lower calories and fat, and they come from local farmers.

Additionally, the dimensions of behavioral modeling had a significantly positive relationship for all the reasons in the selection of food $(p<0: 01, p<0.05)$, that is, the higher the behavioral modeling is done then the children imitate the behavior of reasons in the selection of food through observation. Indirect modeling had a significant relationship with all the reasons in the selection of food ( $p<0: 01, p<0.05$ ), except for price reasons, that is, the higher the indirect modeling is done, then inadvertently child will adopt the behavior in the selection of food especially in vegetables. Parental controls $(p<0.01)$ also had a significant positive relationship to all the reasons for the selection of food, that is, the higher the control that parents do, the more increase the intake in the selection of foods, especially vegetables. However, the exposure of information through the media and friends did not have a relationship in the selection of food.

\section{Factors Influencing Food Selection}

The results of multiple linear regression analysis in this study has a value of Adjusted R2 for 0.305, which means regression model can explain the factors that influence the food selection amounted to 30.5 percent, while 69.5 percent was influenced by other factors which were not examined in this study (Table 4 ). Other variables regarding the food selection was not examined as the situation and mood, knowledge, as well as price.

Based on the regression test results, factors affecting the selection of food were gender, maternal age, parental modeling inadvertently (indirect modeling), and parental controls. Gender has significant effect on the food selection $(\beta=-$ 4.066; $\mathrm{p}<0.05)$. It explains that male students tend to choose to eat vegetables than female. Maternal age has a significant influence on the food selection $(\beta=-$ $0.488 ; \mathrm{p}<0.05)$. In the variable of parental modelling, indirect modeling dimension $(\beta=0.281 ; \mathrm{P}<0.05)$ and parental control $(\beta=0.542 ; \mathrm{P}<0.05)$ significantly influenced the food selection, especially vegetables. 
Table 4 The results of multiple regression analysis between respondent characteristics, family characteristics, parental modeling, parental controls, information exposure on the food selection

\begin{tabular}{|c|c|c|c|}
\hline \multirow[t]{2}{*}{ Variable } & \multicolumn{3}{|c|}{ Food Selection } \\
\hline & $\mathrm{B}$ & $\mathrm{B}$ & Sig. \\
\hline Constant & 1.994 & & \\
\hline $\operatorname{Sex}(0=$ male $; 1=$ female $)$ & -4.066 & -0.155 & $0.004 *$ \\
\hline Pocket money (rupiah) & 0.000 & -0.021 & 0.691 \\
\hline Father age (tahun) & -0.134 & -0.060 & 0.404 \\
\hline Mother age (tahun) & 0.488 & 0.203 & $0.006^{*}$ \\
\hline $\begin{array}{l}\text { Father education }(0=\text { non higher education; } 1=\text { higher } \\
\text { education) }\end{array}$ & -1.538 & -0.059 & 0.348 \\
\hline $\begin{array}{l}\text { Mother education }(0=\text { non higher education; } 1=\text { higher } \\
\text { education) }\end{array}$ & 0.738 & 0.028 & 0.650 \\
\hline \multicolumn{4}{|l|}{ Parental modelling } \\
\hline Verbal modelling & -0.055 & -0.053 & 0.384 \\
\hline Behavioral modelling & 0.115 & 0.114 & 0.074 \\
\hline Indirect modelling & 0.281 & 0.332 & $0.000 * *$ \\
\hline Parental Control & 0.542 & 0.350 & $0.000 * *$ \\
\hline \multicolumn{4}{|l|}{ Information Exposure } \\
\hline Media & 0.030 & 0.037 & 0.491 \\
\hline Friends & -0.041 & -0.059 & 0.278 \\
\hline F & & & 10.712 \\
\hline $\mathrm{R}^{2}$ & & & 0.336 \\
\hline Adjusted $\mathrm{R}^{2}$ & & & 0.305 \\
\hline Sig. & & & 0.000 \\
\hline
\end{tabular}

Note: $*=$ significant at the level of $\mathrm{p}<0.05, * *=$ significant at $\mathrm{p}<0: 01$

\section{Discussion}

This study suggested that there is a vegetable eating habit in students before and after the entry of the college. At the time before signing the college, students are accustomed to eating vegetables by the number of servings of one cup every day, while after entering college vegetable consumption changed with half cup serving both male and female student. The frequency of consumption of vegetables also underwent a change that before entering IPB vegetable consumption frequency was more than twice per day, but after entering the college, this was once per day. In addition, the types of vegetables commonly which were consumed by students before and after entry colleges were the types of stir-fried vegetables. Changes in eating habits of students occurred allegedly because vegetables which were available in the dorm cafeteria were not usually consumed by the students because of the tastes of different flavors when they are in the area of origin or residence.

waktu dengan membandingkan harga sebelum membeli produk makanan.

The results of this study indicated that there were three main reasons in food selection, that is, health, mood, and weight control. This is supported by the results of the study the Sun (2008) that an important reason in the selection is the price of food, mood and sensory appeal. In line with the results of research and Briawan Puspadewi (2014) that the main reason in the food selection is health, 
mood, a natural ingredient in food, weight control and ethical issues. According to Steptoe et al. (1995), he said that the reason of health, sensory appeal, and the price is a major factor in the food selection at the age of 17-89 years. In addition, the results of correlation in this study were that there was a significantly negative relationship between the sexes with the food selection. It showed that male tended to prefer to eat vegetables because of the cheap and affordable price. Price is an obvious influence on the food selection (Steptoe et al. 1995). This is in line with Missagia et al. (2012) who stated that males prefer food that is cheap, but not willing to spend the time to compare the prices of food products, whereas female spend more time comparing prices before buying food products.

In addition, maternal age has a significant relationship with prices and ethical reasons in choosing food. Maternal age students who were in the category of middle age (36-50 years) tended to choose foods which are cheap and affordable prices, as well as products derived from local farmers and packaged with environmentally friendly. This was driven by their mother's experience and understanding of the types of vegetables as well as the provision of healthy food choices for families.

The results also showed that the food selection, especially vegetables was influenced by two variables: indirect dimensional modeling and parental controls. Parental modeling is the behavior, attitudes, or beliefs (both verbal and physical) displayed parents (either intentionally or unintentionally) in the presence of children (Palfreyman et al. 2012). This showed that indirect modeling done by parents was high in the food selection, especially vegetables. Thus, the tendency of children to imitate indirectly choosing foods will also increase, that is, children have adopted their own eating behavior that parents do, but parents do not intentionally try to introduce these foods. This can reinforce the results of these studies by Pearson et al. (2009) that parental modeling and support of parents are positively associated with the consumption of fruits and vegetables. It can be said that parents who demonstrate healthy behaviors in children let children make healthy behaviors as well. Parental controls also have a significant influence on the food selection, especially vegetables. It is thought that control exercised by the parent may be restrictions. In line with the research Bargiota et al. (2013) on teenagers in Greece that the parents exercise control over the food selection, because when teens have dinner with his parents, they eat more healthy foods than that with friends, which they tended to eat foods junk food. On the other hand, the results Ismail et al. (2013) stated that the control of parents, especially mothers, belongs to the environmental factors that have an influence on the diet, and this provides information on the vegetable in terms of taste and benefits.

Other variables influencing the food selection were the characteristics of students such as gender, and family characteristics such as maternal age. Gender had a significant negative influence on the food selections, especially vegetables. It explained that male students tended to choose to eat vegetables than female. According Azrimaidaliza and Punakarya (2011) that males are more variable in the food selection compared with female. In addition, the results of this study also showed that male students tended to consider price reasons, whereas female considered the main reasons - health and weight control in the food selection. In general, females had more knowledge about food with and showed greater 
concern about food safety, health, and weight control (Gibney et al., 2009; Suswanti 2013).

This study showed that maternal age had an influence on the food selection. The results of this study are consistent with Murdiyanta et al. (2015), that is, the mother's age affects the quality of the provision of food choices with their children to support optimal growth and development. According Anggraini (2012) factors, such as parental education, parental controls, and counseling of parents are important to establish the behavior of healthy eating, especially mothers who have an important role in determining the eating habits of children at birth and education level of parents also plays an important role in order to provide healthy food choices. The role of the mother as an agent of socialization contributes in providing the knowledge, skills, and information as well as one of the models that are usually imitated by children. This is in line with Sharma (2011) who said that among other family members, the mother's role becomes more important and the family's social status and gender of children also affect consumer socialization.

Consumer Socialization is the process of young people in acquiring skills, knowledge, and attitudes that are relevant to their function as a consumer in the market (Ward 1974). This is in line with Hota and McGuiggan (2006) the degree of influence of consumer socialization is parents, media (television / advertising) and peers. The influence of parents in the socialization of consumers in this study consisted of parental modeling and parental controls. In addition, the exposure of a person's knowledge, the information will be more open so that the food selection, especially fruits and vegetables would be better (Bahria and Triyanti 2010).

Media and friends in this study were also one of the agents of socialization consumers. Based on the results, it was said that exposure of information through the media does not have a relationship and influence with the food selection. This is not in line with the results of Bahria and Triyanti (2010) who state that there is a tendency of adolescents to consume fruits and vegetables because of the information obtained from the media and its relationship to health. Besides that, friends do not have a relationship and influence on the food selection. This is consistent with research by Bahria and Triyanti (2010) that there is no peer's influence to consume fruits and vegetables.

There is no influence of information exposure through the media and friends in the food selection. It is alleged that the media and friends are not the only persons to get knowledge and information regarding the food selection, especially vegetables. In this study, the role of parents in socializing the food selection through parental modeling, and control of the parents in the past tended to be applied to the student. On the other hand, the effect of information exposure through friends and the media in their late teens or early adulthood tended not to affect the food selection, especially vegetables.

This study has limitations: first, this is lack of control during data retrieval process because it is not monitored directly when filling out the questionnaire. Second, this study only describes the variable of parental modeling and control of parents in the choice of food as perceived by students and not asked directly to their parents. 


\section{Conclusion and Recommendation}

\section{Conclusion}

The results showed that there is a change in the amount and frequency of consumption of vegetables to students before and after IPB entry. Before entering IPB, students used to eat vegetables by the number of servings of one cup with a frequency of more than twice per day. However, students' consumption of vegetables after signing to IPB changes the number of servings of a half cup vegetable consumption and consumption frequency once per day. The role of parents also affects the food choices. It shows that indirect modeling done by parents is high in the food selection, especially vegetables. This makes the tendency of children to imitate indirectly in choosing foods increase. Parental controls also have a significant influence on the food selection, especially vegetables. It is thought that control done by the parents may be restrictions. Male students tend to consider price reasons, whereas female students consider the main reasons - health and weight control in the food selection. The role of the mother as one of the agents of socialization contributes in providing the knowledge, skills, and information as one of the models that is usually imitated by children.

\section{Recommendation}

This study has found an association among gender, maternal age, parental modeling, and control of the parents with the selection of the students to eat, especially vegetables. For parents as a major role in providing knowledge and information, they can increase vegetable consumption in children from an early age, one of which is drinking water mixed with some vegetables - the infused water. For the government, it is expected to raise awareness about vegetable consumption through a variety of programs to increase vegetable consumption for health in the future.

\section{Reference}

Abdieen, Z.U., Salaria, R.M. 2009. Effect of television advertising on children: with special reference to pakistani urban children. [Paper]. Shaheed Zul_kar Ali Bhutto Institute of Science \& Technology (SZABIST), Tersedia pada https://mpra.ub.uni-muenchen.de/22321/.

Anggraini, S. 2012. Environmental factors and the individual factors to do with the consumption of food in the student dormitories University of Indonesia in Depok in 2012 [underthesis]. Depok (ID): University of Indonesia.

Azrimaidaliza, Punakarya, I. 2011. Analysis of food selection in adolescents in the city of Padang, West Sumatra. National Public Health Journal, 6 (1): $17-22$.

Bahria, Triyanti. 2010. Factors associated with fruit and vegetable consumption among adolescents in four high school in West Jakarta. Journal of Public Health, 4 (2): 63-71.

Bargiota, A., Delizona, M., Tsitorus, A., Koukoulis, G.N. (2013). Eating habits and factors affecting food choice of adolescents living in rural areas. HORMONES, 12(2): 246-253. 
Benton, D. 2004. Role of parents in the determination of the food preferences of children and the development of obesity. International Journal of Obesity, 28: 858-869.

Dewi Y. 2013. Descriptive Study: perception and behavior of eating fruits and vegetables in obese children and parents. Student Science Journal Universitas Surabaya. 2 (1): 1-17.

Eertmans, A. 2006. Sensory-affective and other determinant of food choice: their relative importance and variability across individualsand snd situations [disertasi]. Leuven(BE): Chatolic University of Leuven.

Evelhin, L.A., Hadju, V., Najamuddin, U. 2014. Overview of knowledge, attitude, availability and patterns of fruit and vegetable consumption teenagers in North Toraja district [Internet]. Makassar (ID): [download 2016 July 19]. Available

at: http://repository.unhas.ac.id/handle/123456789/11322?show=full

Faber, R.J., Huh, J. 2010. The role of parental mediation in children's consumer socialization on the web [dissertasion]. Minessota(US): University of Minnesota.

Hota, M., McGuiggan, R. 2006. The relative influence of consumer socialization agents on children and adolescents. Journal of European Advances in Consumer Research, 7: 119-124.

Huang T, Harris KJ, Lee R, Kaur H.2003. Assesing overwight, obesity and physical activitiy in college student. Journal of American College Health. 52(2): 83-86.

Ismail, N., Karim, M.S.A., Karim, R., Adzham, N.M., Halim, N.A. 2013. Fruit and vegetable consumption behavior: a qualitative study of Malay adults in Subang Jaya, Selangor. Journal of Agribusiness Marketing, 6: 52-67

Missagia, S.V., de Oliveira, S.R., de Rezende, A.C. 2012. Food choice motives and healthy eating: assessing gender differences. Journal of EnANPAD, 36: 22-26

Murdiyanta, C.C., Sulistiyani, Ramani, A. (2015). Maternal factors in the food selection in autistic children at Special School Arya Satya Heart Pasuruan [Internet]. Jember (ID): University of Jember [downloadable August 12, 2016]. Available at: http://repository.unej.ac.id/bitstream/handle/123456789/73856/Citra\%20Ca priana\%20Murdiyanta.pdf? sequence $=1$.

Ogden J. 2010. The Phsychology of Eating: From Healthy to Disordered Behavior 2nd. Blackwell Publishing.

Palfreyman, Z., Haycraft, E., Meyer, C. 2012. Development of the Parental Parental modeling Behaviors scale (PARM): links with food intake among children and their mothers. Journal of Maternal and Child Nutrition. DOI: 10.1111/j.1740-8709.2012.00438.x

Palfreyman, Z., Haycraft, E., Meyer, C. 2014. Parental parental modeling of eating behaviors: observational validation of the Parental Parental modeling of Eating Behaviors scale (PARM). Appetite, 86: 31-37.

Pearson, N., Timperio, A., Salmon, J., Crawford, D., Biddle, S.J.H. 2009. Family influence on children's physical activity and fruit and vegetable consumption. International Journal of Behavioral Nutrition and Physical Activity, 6: 34. 
Perera, T., Madhujith, T. 2012. The Pattern of Consumption of Fruits and Vegetables by Undergraduate Students: A Case Study, 23(3): 261-271.

Puspadewi, H., Briawan, D. 2014. The perception of healthy food, motives in food selection, and healthy eating habits in students. Food Nutrition Journal, 9 (3): 211-218.

Sabri MF, Masud J, Paim L. 2005. Consumer socialization among college student in Malaysia. Consumer Interest Annual. 51: 251-254.

Scaglioni, S., Salvioni, M., Galimberti, C. 2008. Influence of parental attitudes in the development of children eating behavior. British Journal of Nutrition, 99: 22-25.

Scheinfeld, E.M. 2012. Healthy eating behaviors of college students in early adulthood understanding through childhood parental influence and the integrative model behavior [tesis].Athens ( ): The University of Georgia.

Sharma, A. 2011. Role family in consumer socialization of children: literature riview. Journal of Arts, Science \& Commerce, 2(3): ISSN 2231-4172.

Shek, D.T.L. 2008. Perceived parental control in Chinese adolescent in Hongkong: a three-year longitudinal study. The Open Family Studies Journal, 1: 7-16.

Steptoe, A., Pollard, T.M., Wardle, J. 1995. Development of a measure of the motives underlying the food selection: the Food Choice Questionnaire. Journal of Appetite, 25: 267-284.

Sun, Y.C. 2008. Health concern, food choice motives, and atitudes toward healthy eating: the mediating role of food choice motives. Appetite, 51(1): 42-49.

Suswanti, I. 2013. Factors associated with the selection of fast food on a medico and health sciences UIN Syarif Hidayatullah Jakarta [underthesis]. Jakarta (ID): State Islamic University Syarif Hidayatullah.

Sztainer, D.N., Story, M., Perry, C., Casey, M.A. 1999. Factors influencing food choices of adolescents: findings from focus-group discussion with adolescents. Journal of The American Dietetic Association, 99(8): 929-937.

Thiruselvakumar, D., Sinuvasan, K., Chakravarthy, R., Venkatesh, E. 2014. Factors affecting food choice and attitude of choosing food items among adolescents in South India. International Journal of Scientific and Research Publication, 4(4): ISSN 2250-315.

Ward, S. 1974. Consumer socialization. Journal of Consumer Research, 1: 1-14.

Yuliati, L.N., Retnaningsih, Aprilia, D. 2012. The influence of the reference group to the awareness and consumption of red rice (Oryza sativa). Journal of Family and Consumer Sciences, 5 (2): 166-174. 